\title{
Consumption Adjustments of Turkish Consumers During The Global Financial Crisis
}

\author{
Nazlı ALIMEN' ${ }^{\prime}$ Gül BAYRAKTAROĞLU²
}

\begin{abstract}
The impacts of the global financial crisis, which started in 2007 and affected both developed and developing countries, were felt in not only banking and finance sectors but also people's way of living and consumption. The purpose of this paper is to reveal the impacts of the global financial crisis on Turkish consumers and compare these effects with respect to demographic factors. According to the findings, 35 consumption adjustment statements are grouped under seven dimensions: Cautious spending, simplicity in purchase and distribution, product adjustments, quest for low price, financial anxiety, promotion adjustments, and awareness. The ANOVA and t-test results demonstrate that 436 respondents made adjustments in these dimensions with significant differences regarding their gender, age, marital status, occupation, and income.
\end{abstract}

Keywords: Financial crisis; consumption adjustments; Turkish consumers

\section{INTRODUCTION}

The global financial crisis started in 2007 and its effects were first felt in the real estate and banking sectors in the United States. It subsequently spread rapidly throughout the world, affecting financial and economic activities, and institutions (Whitney, 2009). Studies on the crisis carried out so far are at macro level, focusing on issues such as reasons behind the crisis, its effects, direction, and consequences (e.g. Allen and Snyder, 2009; French et al., 2009; Reinhart and Rogoff, 2008; Selçuk and Yılmaz, 2010; Susam and Bakkal, 2008). However, there seems to be no research analyzing its impacts on consumers, even though crises affect also individuals through issues such as interest rates, employment, and income. Furthermore, in the literature, few studies analyze consumption adjustments to various crises (e.g. Ang, 2001a, 2001b; Shama 1978, 1981). Therefore, there is a need for analyzing consumption behavior during crises to enhance our knowledge, and understand and better serve the needs of consumers in these difficult times. The purpose of this paper is to monitor trends in consumption behavior during a crisis by analyzing Turkish consumers, determining the changes in consumption behavior and comparing these changes with respect to their demographic variables. The paper starts by reviewing the related literature on financial crisis, consumption behavior during crisis, and the global financial crisis. It is followed by methodology, findings, and conclusion sections.

\section{LITERATURE REVIEW}

\subsection{The Global Financial Crisis: The World and Turkey}

The September 2008 blowout caused industrial production, trade and employment to decrease. In 2009, due to the deep contractions in advanced economies and instant slowdowns in developing economies, the world real GDP was expected to drop. Consumer price projections were expected to be $-0.2 \%$ and $0.3 \%$ in advanced and $5.7 \%$ and $4.7 \%$ in emerging economies in 2009 and 2010 respectively ${ }^{1}$.

It was claimed that the developed countries were more affected by the global financial crisis than developing ones (Özkan, 2008). It was also argued that its effects on Turkey were relatively few due to a more structured financial system and a better developed control system as a consequence of the 2001 crisis (Aydin, 2009). However, the crisis had inevitable effects on countries with low competitive power, a production structure dependent on imports, and a high level of exchange deficit, such as Turkey (Uzunoğlu, 2009). Its impacts on Turkish economy were in terms of economic growth, inflation and exchange rates, exports, and foreign capital (Selçuk and Yılmaz, 2010). In addition, shrinkage in developed economies had an effect on various sectors of Turkish economy, e.g. tourism (Yıldız and Durgun, 2010).

\footnotetext{
Izmir University of Economics, Institute of Social Sciences, Business Administration Doctorate Program Student, nazlialimen@gmail.com

2 Assoc. Prof., Dokuz Eylul University, Faculty of Business, Department of Business Administration, Production Management and Marketing Division, gul.bayraktar@deu.edu.tr
} 


\subsection{Financial Crisis and Consumption}

Hard economic times which cause shortages, inflation, recession and stagflation influence consumers' actualities and expectations about wages, employment, products, services, and prices. As a consequence of financial crises, businesses face with increases in costs of production and reduction in their revenues. This might force businesses not to recruit new workers or even worse, they might be left with no choice but fire some of the workers. This reality increases the risk of unemployment. Households facing greater risk of unemployment are more likely to postpone their durable purchases (Duygan, 2005).

Consumers adapt themselves to the new economic situation (Shama, 1978, 1981) to the extent that they are less willing to spend due to a decrease in their income (Ang, 2001a). They tend to prefer substitutes, postpone purchase of durables, repair more, and provide some services or products for themselves ${ }^{2}$. McKenzie (2006) revealed that consumption of semidurable goods like clothing, glassware and entertainment equipment is reduced in order to compensate increase in the prices of basic necessities such as grains, eggs, oil, and vegetables.

Hence, consumers adjust their consumption during crisis. 18 consumer adjustments were distinguished and grouped under five categories in a survey conducted among US consumers: General, price, product, place, and promotion adjustments (Shama, 1978). In a later study, these categories were used, in the form of 19 statements, to reveal the effects of stagflation on US consumers in 1976 and 1978 caused by the 1973 oil crisis. According to the results, consumers purchased less, spent more time shopping, attempted to buy wholesale, and used more promotion coupons. For durable goods, they paid more attention to product utility and price. Furthermore, they sought cheaper products such as private labels, saved less and used more loans (Shama, 1981). Also, a conceptul review about consumption behavior during crisis (Ang et al., 2000) suggested five adjustment categories as product, price, promotion, and shopping adjustments, and general reactions. Ang (2001b), on the other hand, evaluated Asian consumers' adjustments during the 1997 Asian crisis using 21 statements, including sixteen from Shama (1978, 1981), grouped under five categories: Impacts, price, product, promotion, and distribution adjustments. Therefore, in previous studies (Ang, 2001a, 2001b; Ang et al., 2000; Shama, 1978, 1981), consumption adjustments were categorized in accordance with the marketing mix, in addition to general impacts summarized in Table1.

While a number of studies investigating the effects of crisis aimed to find out how consumers adjusted their consumption (Ang, 2001a, 2001b; Ang et al., 2000; Shama, 1978, 1981), some others focused on specific issues like changes in household welfare in Indonesia (Friedman and Levinsohn, 2002) and health-care consumption in Korea (Yang et al., 2001), obtaining valuable findings for further research.

\section{Table 1: The Summary of Adjustment Categories Used in the Previous Studies*}

\begin{tabular}{|c|c|}
\hline Adjustment categories & Statements \\
\hline General impacts & $\begin{array}{l}* \text { decrease in lavishness } \\
* \text { increase in information search in the decision-making process and in energy consciousness } \\
* \text { discussion of purchase decisions with spouse }\end{array}$ \\
\hline Product adjustments & $\begin{array}{l}* \text { emphasizing product durability } \\
* \text { preference of local rather than foreign products } \\
* \text { purchase of necessities rather than luxuries } \\
* \text { purchase of smaller packages } \\
* \text { become a do-it-yourself person } \\
\end{array}$ \\
\hline Price adjustments & $\begin{array}{l}* \text { being more careful with money } \\
* \text { shopping for specials and bargains } \\
* \text { using more credits } \\
* \text { saving less } \\
* \text { evaluating value for money } \\
* \text { giving importance to cheaper prices }\end{array}$ \\
\hline $\begin{array}{l}\text { Promotion } \\
\text { adjustments }\end{array}$ & $\begin{array}{l}* \text { reduced attraction of free gifts } \\
* \text { preference for informative rather than imagery-based advertisements } \\
* \text { asking salesperson more questions before making a purchase } \\
* \text { believing in advertising claims less than before }\end{array}$ \\
\hline Place adjustments & $\begin{array}{l}\text { * shopping at discount and neighborhood stores, wholesale outlets and cut-rate stores more than before } \\
* \text { preferring small-personal stores rather than department stores } \\
* \text { reducing end-of-aisle impulse purchases }\end{array}$ \\
\hline
\end{tabular}

* Source: Organized by the authors using the studies of Ang (2001a; 2001b), Ang et al. (2000), and Shama (1978, 1981). 
Altunışık et al. (2003) revealed that during the Turkish 2001 crisis, consumers tended to invest more, lowered their spending, and became more price sensitive, more comparative shoppers and more conscious of sales promotions. Moreover, they looked for functionality more and postponed renewal purchases. In February 2009, 81\% of British consumers claimed to be affected by the crisis, reducing grocery expenditures by $33 \%$ and home improvements by $51 \%$. Dining out and shopping activities decreased by $54 \%$ and $56 \%$, respectively. Furthermore, the number of people who trusted banks deteriorated by $54 \%$ within three months. However, the British continued to go abroad for vacation abroad, but spent less on non-essentials (Fernandez, 2009). According to a survey by the Nielsen research company, the product categories on which Turkish consumers limited spending during the global financial crisis were clothing, holidays, entertainment, cosmetics, and durable goods ${ }^{3}$.

\section{RESEARCH METHODOLOGY}

\subsection{Research Objective}

The purpose of this paper is to reveal possible changes in consumption behavior of Turkish consumers and group these changes under related adjustment dimensions. It aims to discover how consumers adapt consumption behavior and compare these adaptations with respect to demographic variables. In addition, this study attempts to develop a scale to measure consumption adjustments during crises and to determine types of adjustments Turkish consumers utilized more during the recent crisis.

\subsection{Hypotheses and the Research Model}

One of the purposes of this study is to determine consumption adjustment dimensions. Hence, our first research question:

$\mathrm{RQ}_{1}$ : What are the consumption adjustment dimensions?

In addition, the measurement items used in previous studies are not exactly the same. Therefore, we aim to develop a new measurement scale by reviewing the literature and combining the items used in previous studies. Since the reliability of the new measurement scale needs to be tested, the next research question is:

$R_{2}$ : Does the consumption adjustment measurement tool developed have sufficient reliability scores?
In the previous studies, consumption adjustments were grouped with respect to marketing mix categories and differentiated in accordance with time, background of crisis, and respondents' individual characteristics (Ang, 2001b; Ang et al., 2000; Shama, 1978, 1981). In addition, region, socio-economic and demographic features of individuals, households, and communities were other factors causing alterations in consumption (Frankenberg et al., 1999).

The study also aims to test whether there are any significant effects of consumers' demographic characteristics (gender, age, occupation, marital status, and income) on the consumption adjustment dimensions (Figure 1). Therefore, six hypotheses are developed as follows:

$\mathrm{H}_{1}$ : There is a significant difference between consumers' adjustment levels with respect to the adjustment categories.

$\mathrm{H}_{2}$ : Age constitutes a significant difference in consumers adjustment levels.

$\mathrm{H}_{3}$ : Occupation constitutes a significant difference in consumers adjustment levels.

$\mathrm{H}_{4}$ : Income constitutes a significant difference in consumers adjustment levels.

$\mathrm{H}_{5}$ : Gender constitutes a significant difference in consumers adjustment levels.

$\mathrm{H}_{6}$ : Marital status constitutes a significant difference in consumers adjustment levels.

\begin{tabular}{|l|l|}
\hline DEMOGRAPHIC VARIABLES \\
- Gender \\
- Age \\
- Occupation \\
- Income \\
- Marital status
\end{tabular}$\longrightarrow \begin{aligned} & \\
& \text { CONSUMPTION } \\
& \text { ADJUSTMENTS }\end{aligned}$

Figure 1: Research Model

\subsection{Questionnaire Design}

The questionnaire consisted of two parts. The first part aimed to reveal consumption adjustments during the 2007 crisis. To measure the adjustment levels of the respondents, total number of 37 statements related to product, price, promotion and place adjustments, and general impacts of crisis from the studies of Shama (1978), Ang et al. (2000) and Ang (2001b) were utilized on a 5-point Likert scale, ranging from $1=$ Strongly disagree to $5=$ Strongly agree. Statements include "As a consumer, I have changed my habits and preferences" and "I believe advertising claims less than I used to". The second part consisted of questions re- 
lating to demographic variables such as gender, age, occupation, income, and marital status.

\subsection{Sampling Method}

As the effects of the crisis reached its peak level with the bankruptcy of Lehman in September 2008, the crisis became an important issue also in Turkey. It was argued that the crisis would affect the country deeply; therefore, we decided to investigate whether the crisis had an impact on individuals, namely consumers. After the collection of secondary data and preparation of the questionnaire, we distributed the questionnaires in May and June 2009.

Consumers in a shopping mall were thought to exercise the shopping behavior. Therefore, they could readily answer questions on how they adjust their consumption behavior. In addition, consumers tend to adjust their consumption less on necessities than luxuries. In shopping malls, generally apparel and home decoration products are sold which cannot be considered necesities. Therefore, consumers visiting shopping malls might have developed some adjustments in their shopping and consumption behavior. Since visitors of shopping malls would fit our study objectives, we chose three shopping malls in different districts of Izmir. A structured convenience sampling was used by selecting different respondents with respect to their demographics. For that purpose, questionnaires were applied throughout the week, at different times of day because the profile of the visitors of those malls might vary from weekdays to weekends, 450 questionnaires were distributed and collected. 14 improperly completed questionnaires were excluded, leaving 436 ques- tionnaires for the analysis, a response rate of $97 \%$. Furthermore, the sample size of 436 can be considered as appropriate for a study consisting of 37 variables, both for conducting factor analysis, and for a city whose population is close to 4 million (Cohen, 1969; Krejcie and Morgan, 1970; Roscoe, 1975).

\subsection{Data Analysis}

Frequency analyses, mean distribution and reliability analysis were conducted. Since a new adjustment measurement was developed by combining statements used in several previous studies, a factor analysis was applied to determine adjustment dimensions. Following this, t-test and one-way ANOVA analyses were applied to compare the responses of the participants with respect to their demographic characteristics.

\section{FINDINGS}

\subsection{Sample Profile}

Nearly one third of 436 respondents were female (31.7\%) while $68.3 \%$ were male. The average age was 34.4. The majority were below the age of 37. Single respondents made up $37.6 \%$ of the sample, showing that the majority were married. More than one third were laborers (37.4\%), followed by students $(27.2 \%)$, engineers $(14.7 \%)$, teachers $(7.3 \%)$, accountants (3.8\%), and housewives (3.2\%), respectively. 38.4\% worked in the public sector, and $31.1 \%$ in the private. The unemployed and retired comprised $20.5 \%$ and $2.1 \%$, of the sample, respectively (presented in Table 2).

\section{Table 2: Sample Profile}

\begin{tabular}{|c|c|c|c|c|c|c|c|}
\hline \multicolumn{8}{|c|}{ Sample Profile } \\
\hline & & $\mathbf{n}$ & $\%$ & & & $\mathbf{n}$ & $\%$ \\
\hline \multirow{5}{*}{ Gender } & Male & 298 & 68.3 & \multirow{8}{*}{ Occupation } & Laborer & 117 & 37.4 \\
\hline & Female & 138 & 31.7 & & Student & 85 & 27.2 \\
\hline & Total & 436 & 100 & & Engineer & 46 & 14.7 \\
\hline & $18-27$ & 146 & 33.5 & & Teacher & 23 & 7.3 \\
\hline & $28-37$ & 137 & 31.4 & & Accountant & 12 & 3.8 \\
\hline \multirow[t]{5}{*}{ Age } & $38-47$ & 80 & 18.3 & & Housewife & 10 & 3.2 \\
\hline & 48 and above & 73 & 16.7 & & Other* & 20 & 6.4 \\
\hline & Total & 436 & 100.0 & & Total & 313 & 100.0 \\
\hline & Public & 163 & 38.4 & \multirow{4}{*}{ Income } & $0-1000$ & 155 & 38.0 \\
\hline & Private & 132 & 31.1 & & $1001-2000$ & 161 & 39.5 \\
\hline \multirow{5}{*}{$\begin{array}{l}\text { Business } \\
\text { Type }\end{array}$} & Unemployed & 87 & 20.5 & & 2001 and above & 92 & 22.5 \\
\hline & Self -employed & 33 & 7.8 & & Total & 408 & 100.0 \\
\hline & Retired & 9 & 2.1 & & Single & 164 & 37.6 \\
\hline & Total & 424 & 100.0 & Marital Status & Married & 272 & 62.4 \\
\hline & & & & & Total & 436 & 100 \\
\hline
\end{tabular}

* Doctor, nurse, academic, press member, librarian, government officer, electronic technician, software specialist, and security personnel. 


\subsection{Reliability and Factor Analyses}

The Cronbach Alpha of the consumer adjustments scale was 0.95 . Prior to performing t-test and ANOVA, factor analysis was applied to reduce the data and to find the adjustment dimensions (Sheth, 1970). The Kaiser-Meyer-Oklin value was 0.95 and the Bartlett's Test of Sphericity reached statistical significance $(p=0.00)$, thus both supported the factorability of the correlation matrix (Kaiser and Rice, 1974). Performing varimax rotation, the presence of seven components with eigenvalues exceeding 1, explaining $59.48 \%$ of the total variance was revealed (Table 3). Statements having factor loadings below 0.4 , "I weigh purchase decisions with my spouse more than I used to" and "I bargain for lower prices more than I used to", were excluded from the factor analysis.

According to the results, the first six factors, cautious spending $(a=.90)$, simplicity in purchase and distribution ( $a=.81)$, value seeking $(\alpha=.72)$, quest for low price $(a=.80)$, promotion adjustments $(a=.79)$, and financial anxiety $(a=.67)$ were found to have Cronbach Alpha scores above 0.60 which proves that the measurement was reliable (Malhotra, 2007). On the other hand, the Cronbach Alpha score of the awareness dimension was 0.46 , below the acceptable value of 0.60 . Thus, this dimension needs to be improved.

Table 3: Varimax Rotation of Seven Factor Solution of the Consumer Adjustments Statements

\begin{tabular}{|c|c|c|c|c|c|c|c|}
\hline Items & $\begin{array}{c}\text { Factor } \\
1\end{array}$ & $\begin{array}{l}\text { Factor } \\
2\end{array}$ & $\begin{array}{c}\text { Factor } \\
3\end{array}$ & $\begin{array}{c}\text { Factor } \\
4\end{array}$ & $\begin{array}{l}\text { Factor } \\
5\end{array}$ & $\begin{array}{c}\text { Factor } \\
6\end{array}$ & $\begin{array}{c}\text { Factor } \\
7\end{array}$ \\
\hline \multicolumn{8}{|l|}{ Factor 1: Cautious Spending } \\
\hline $\begin{array}{l}\text { As a consumer, I have changed my habits and } \\
\text { preferences. } \\
\text { I judge products and services in a new way. } \\
\text { I became more of a comparative shopper. } \\
\text { I became less wasteful. } \\
\text { I buy less of everything. } \\
\text { Instead of shopping, I am contented with window } \\
\text { shopping. } \\
\text { I look for more information on } \\
\text { products before buying. } \\
\text { I must work harder to be able to afford my present way } \\
\text { of life. } \\
\text { I evaluate product life cycle costs-durability and value } \\
\text { for money more than I used to. } \\
\text { As a consumer, I am more frustrated than I used to. } \\
\text { I am more careful with money. }\end{array}$ & $\begin{array}{l}0.74 \\
0.71 \\
0.77 \\
0.56 \\
0.59 \\
0.47 \\
0.51 \\
0.60 \\
0.56 \\
0.59 \\
0.61 \\
\end{array}$ & & $\begin{array}{l}0.48 \\
0.47 \\
\end{array}$ & & & & \\
\hline \multicolumn{8}{|l|}{ Factor 2: Simplicity In Purchase and Distribution } \\
\hline $\begin{array}{l}\text { I became a do-it-yourself person. } \\
\text { I prefer local rather than foreign brands. } \\
\text { I buy products in smaller packages. } \\
\text { I shop at neighborhood stores more often than I used to. } \\
\text { I shop at stores in the downtown area less often than I } \\
\text { used to. } \\
\text { I now prefer to shop at small, personal stores over } \\
\text { gigantic, department stores. }\end{array}$ & & $\begin{array}{l}0.44 \\
0.69 \\
0.61 \\
0.67 \\
0.64 \\
0.71\end{array}$ & & & & & \\
\hline \multicolumn{8}{|l|}{ Factor 3: Product Adjustments } \\
\hline $\begin{array}{l}\text { Product durability is now more important for me. } \\
\text { I value fuel economy in cars. } \\
\text { I buy necessities rather than luxuries. }\end{array}$ & 0.41 & & $\begin{array}{l}0.55 \\
0.59 \\
0.61\end{array}$ & & & & \\
\hline \multicolumn{8}{|l|}{ Factor 4: Quest for Low Price } \\
\hline I shop for specials and bargains more than I used to. & & & & 0.66 & & & \\
\hline \multirow{3}{*}{$\begin{array}{l}\text { I look for cheaper products. } \\
\text { I shop from wholesale outlets more than before. } \\
\text { I shop at cut-rate stores more than before. }\end{array}$} & & & 0.41 & 0.42 & & & \\
\hline & & 0.50 & & 0.58 & & & \\
\hline & & & & 0.72 & & & \\
\hline I pay more attention to sales promotions. & & & & 0.65 & & 0.47 & \\
\hline \multicolumn{8}{|l|}{ Factor 5: Financial Anxiety } \\
\hline I use more credits. & & & & & 0.68 & & \\
\hline I save less. & & & 0.47 & & 0.54 & & \\
\hline I became insecure about my job. & & & & & 0.42 & & \\
\hline I find it harder to make ends meet. & 0.47 & & & & 0.49 & & \\
\hline \multicolumn{8}{|l|}{ Factor 6: Promotion Adjustments } \\
\hline I believe in advertising claims less than I used to. & & & & & & 0.47 & \\
\hline $\begin{array}{l}\text { I now look for ads that give me information about what } \\
\text { the product can do for me. }\end{array}$ & & & & & & 0.72 & \\
\hline I now rely less on ads that use imagery. & & & & & & 0.74 & \\
\hline $\begin{array}{l}\text { I ask the salesperson more questions now before I make } \\
\text { a purchase. }\end{array}$ & & & & & & 0.49 & \\
\hline \multicolumn{8}{|l|}{ Factor 7: Awareness } \\
\hline I am more energy conscious. & 0.43 & & & & & & 0.49 \\
\hline I argue more about financial matters. & & & & & & & 0.76 \\
\hline$\%$ of variance explained & 15.52 & 10.60 & 8.32 & 7.51 & 6.57 & 6.44 & 4.50 \\
\hline Coefficient Alpha & 0.90 & 0.81 & 0.72 & 0.80 & 0.79 & 0.67 & 0.46 \\
\hline
\end{tabular}


Prior researchers had generally categorized consumption adjustments under five groups regarding the marketing mix elements as product, price, place, and promotion adjustments, in addition to the general impacts category (Ang, 2001b; Shama, 1978, 1981). Similar categories were also found in this study; however, the dimensions were renamed to reflect more precise representation of the categories, such as "cautious spending", "simplicity in purchase and distribution", "product adjustment", "quest for low price", and "promotion" adjustment. This study differed from the previous studies with the addition of two adjustment dimensions, "financial anxiety" and "awareness".

\subsection{Hypotheses Testing}

Table 4: Mean Values of Adjustment Statements

\subsubsection{Mean Distributions of the Adjustment Dimensions}

All of the mean values of the dimensions were either above 3 pointing out that the respondents adjusted their consumption behavior during the crisis except the "simplicity in purchase and distribution" dimension which has a mean value very close to 3 and found not to be significantly different from the midpoint value 3 using one sample t-test (Table 4).

Using dummy variables for each dimension, a one-way ANOVA analysis showed a very significant difference $(p=.00)$ between the mean values of the dimensions. Therefore, $\mathrm{H}_{1}$ was supported, There was a significant difference between the adjustment levels of the consumers with respect to the adjustment categories.

\begin{tabular}{|c|c|c|c|}
\hline Items* & $\mu \pm s d$ & Items & $\mu \pm s d$ \\
\hline Cautious Spending & $3.64 \pm 0.86$ & Product Adjustments & $3.91 \pm 0.89$ \\
\hline $\begin{array}{l}\text { As a consumer, I have changed my habits } \\
\text { and preferences. }\end{array}$ & $3.38 \pm 1.30$ & Product durability is now more important for me. & $3.92 \pm 1.11$ \\
\hline I judge products and services in a new way. & $3.61 \pm 1.13$ & I value fuel economy in cars. & $3.73 \pm 1.21$ \\
\hline I became more of a comparative shopper. & $3.82 \pm 1.21$ & I buy necessities rather than luxuries. & $4.07 \pm 1.02$ \\
\hline I became less wasteful. & $3.94 \pm 1.11$ & Quest for Low Price & $3.42 \pm 0.89$ \\
\hline I buy less of everything. & $3.38 \pm 1.23$ & I look for cheaper products. & $3.47 \pm 1.21$ \\
\hline $\begin{array}{l}\text { Instead of shopping, I am contented with } \\
\text { window shopping. }\end{array}$ & $2.97 \pm 1.20$ & $\begin{array}{l}\text { I shop for specials and bargains more than I used } \\
\text { to. }\end{array}$ & $3.49 \pm 1.21$ \\
\hline $\begin{array}{l}\text { I look for more information on products } \\
\text { before buying. }\end{array}$ & $3.71 \pm 1.16$ & I shop from wholesale outlets more than before. & $3.33 \pm 1.21$ \\
\hline \multirow{2}{*}{$\begin{array}{l}\text { I must work harder to be able to afford my } \\
\text { present way of life. }\end{array}$} & \multirow{2}{*}{$3.64 \pm 1.27$} & I shop at cut-rate stores more than before. & $3.37 \pm 1.18$ \\
\hline & & I pay more attention to sales promotions. & $3.41 \pm 1.18$ \\
\hline \multirow{3}{*}{$\begin{array}{l}\text { I evaluate product life cycle costs-durability } \\
\text { and value for money more than I used to. }\end{array}$} & \multirow{3}{*}{$3.96 \pm 1.11$} & Financial Anxiety & $3.21 \pm 0.95$ \\
\hline & & I use more credits. & $2.72 \pm 1.39$ \\
\hline & & I save less. & $3.68 \pm 1.30$ \\
\hline \multirow{2}{*}{$\begin{array}{l}\text { As a consumer, I am more frustrated than I } \\
\text { used to. }\end{array}$} & \multirow[b]{2}{*}{$3.61 \pm 1.22$} & I became insecure about my job. & $3.07 \pm 1.36$ \\
\hline & & I find it harder to make ends meet. & $3.34 \pm 1.34$ \\
\hline I am more careful with money. & $4.00 \pm 1.03$ & Promotion Adjustments & $3.48 \pm 0.91$ \\
\hline Simplicity in Purchase and Distribution & $3.07 \pm 0.87$ & I now rely less on ads that use imagery. & $3.17 \pm 1.16$ \\
\hline I became a do-it-yourself person. & $2.88 \pm 1.27$ & I believe in advertising claims less than I used to. & $3.66 \pm 1.18$ \\
\hline $\begin{array}{l}\text { I shop at neighborhood stores more often } \\
\text { than I used to. }\end{array}$ & $2.97 \pm 1.21$ & $\begin{array}{l}\text { I now look for ads that give me information about } \\
\text { what the product can do for me. }\end{array}$ & $3.51 \pm 1.13$ \\
\hline $\begin{array}{l}\text { I shop at stores in the downtown area less } \\
\text { often than I used to. }\end{array}$ & $3.10 \pm 1.18$ & $\begin{array}{l}\text { I ask the salesperson more questions now before I } \\
\text { make a purchase. }\end{array}$ & $3.55 \pm 1.18$ \\
\hline \multirow{2}{*}{$\begin{array}{l}\text { I now prefer to shop at small, personal } \\
\text { stores over gigantic, department stores. }\end{array}$} & \multirow[b]{2}{*}{$2.86 \pm 1.21$} & Awareness & $3.69 \pm 0.92$ \\
\hline & & I am more energy conscious. & $3.99 \pm 1.15$ \\
\hline I prefer local rather than foreign brands. & $3.50 \pm 1.23$ & I argue more about financial matters. & $3.39 \pm 1.14$ \\
\hline
\end{tabular}

* 5-point Likert scale is used to assess statements ranging from $1=$ Strongly disagree to $5=$ Strongly agree.

The "product adjustments" dimension with the highest mean score $(\mu=3.91 \pm 0.89)$ demonstrated that the respondents mostly adjusted themselves in terms of products, followed by "awareness" ( $\mu=3.69 \pm 0.92)$, "cautious spending" $(\mu=3.64 \pm 0.86)$, "promotion adjustments" $(\mu=3.4 \pm 0.91)$, "quest for low price" ( $\mu=3.42 \pm 0.89)$, "financial anxiety" $(\mu=3.21 \pm 0.95)$, and "simplicity in purchase and distribution" $(\mu=3.07 \pm 0.87)$ dimensions. 


\subsubsection{Influence of Age}

A one-way analysis of variance was conducted to explore the impacts of age, occupation, income, and business type. There was a statistically significant difference between age groups in the promotion adjustment category $(\mathrm{F}=3.44, \mathrm{p}=0.02)$ indicating that consumers' adjustments in the promotion category differed with respect to age. Respondents between 18-27 had a mean score of $\mu=3.33 \pm 0.89$ whereas the ones older than 48 had a mean score of $\mu=3.69 \pm 0.80$. The mean scores of promotion adjustments increased as age increased. This demonstrates that as people get older, they tend to look for more informative promotional activities. Therefore, $\mathrm{H}_{2}$ was supported for the promotion adjustments.

\subsubsection{Influence of Occupation}

$\mathrm{H}_{3}$ aimed to test occupation's impact on the adjustment levels of consumers. The results of the oneway ANOVA showed significant differences at the $p<0.05$ level between occupation groups for cautious spending $(F=2.50, p=0.02)$, simplicity in purchase and distribution $(F=3.11, p=0.01)$, quest for low price $(F=2.38, p=0.03)$, financial anxiety $(F=2.83$, $\mathrm{p}=0.01)$, and promotion adjustments $(\mathrm{F}=2.83$, $\mathrm{p}=0.01$ ) as shown in Table 5 .

In general, students and accountants tended to adjust less than laborers, teachers and other occupation groups including doctors, nurses, academics, press members, librarians, government officers, electronic technicians, software specialists, and security personnel. There were significant differences between students and laborers in "simplicity in purchase and distribution" $\left(\mu_{\text {student }}=2.85\right.$ $\left.\pm 0.77, \mu_{\text {laborer }}=3.31 \pm 0.91\right)$ dimension and "promotion" dimension $\left(\mu_{\text {student }}=3.26 \pm 0.87, \mu_{\text {laborer }}=3.65\right.$ \pm 0.90 ). Furthermore, students had significantly lower scores than the teachers do in "promotion" adjustment dimension ( $\mu_{\text {student }}=3.26 \pm 0.87$, $\left.\mu_{\text {teacher }}=3.93 \pm 0.77\right)$. These findings indicate that students significantly adjust less in these two dimensions.

Also accountants had significantly lower mean scores than teachers $\left(\mu_{\text {accountant }}=3.00 \pm 0.84\right.$, $\left.\mu_{\text {teacher }}=3.98 \pm 0.89\right)$ in "cautious spending"; than other occupation groups ( $\mu_{\text {accountant }}=2.87 \pm 0.57$, $\left.\mu_{\text {other }}=3.87 \pm 0.85\right)$ in "quest for low price", and than laborers $\left(\mu_{\text {accountant }}=3.02 \pm 0.81, \mu_{\text {laborerr }}=3.41 \pm 0.98\right.$ ) in "financial anxiety" dimensions. It is interesting that accountants scored significantly lower than some of the occupation groups in three dimensions which are related to financial and pricing issues, i.e. "cautious spending", "quest for low price", and "financial anxiety". Since accountants deal with these issues in their profession, they might be more confident in their spending. They might be used to spend their money cautiously not only during crisis but throughout their life.

Table 5: The Influence of Occupation on Adjustment Dimensions

\begin{tabular}{|l|c|c|}
\hline \multicolumn{1}{|c|}{ Adjustment Categories } & \multicolumn{2}{c|}{ p $^{*}$} \\
\hline Cautious Spending & 2.50 & 0.02 \\
\hline Simplicity in Purchase and Distribution & 3.11 & 0.01 \\
\hline Quest for Low Price & 2.38 & 0.03 \\
\hline Financial Anxiety & 3.22 & 0.00 \\
\hline Promotion Adjustments & 2.83 & 0.01 \\
\hline
\end{tabular}

$* p<0.05$

Therefore, $\mathrm{H}_{3}$ was supported that occupation was found to have an impact on the adjustment levels of consumers in the cautious spending, simplicity in purchase and distribution, quest for low price, financial anxiety and the promotion adjustment dimensions. Especially accountants and students created a difference in their adjustment levels among all occupation groups by adjusting less.

\subsubsection{Influence of Income}

The one-way ANOVA test results showed that income constituted significant differences in the mean values of three dimensions: the cautious spending $(F=3.25, p=0.04)$, quest for low price $(F=7.26, p=0.00)$, and the financial anxiety $(F=4.50, p=0.01)$ as shown in Table 6. In other words, cautious spending, quest for low price, and financial anxiety dimensions significant differ with rspect to income levels of the respondents. 
Table 6: The Influence of Income on Adjustment Dimensions

\begin{tabular}{|l|c|c|}
\hline \multicolumn{1}{|c|}{ Adjustment Categories } & \multicolumn{2}{c|}{ p $^{*}$} \\
\hline Cautious Spending & 3.25 & 0.04 \\
\hline Quest for Low Price & 7.26 & 0.00 \\
\hline Financial Anxiety & 4.50 & 0.01 \\
\hline
\end{tabular}

$* p<0.05$

Hence, $\mathrm{H}_{4}$ was supported for the cautious spending, quest for low price, and the financial anxiety. In general, the lower income groups (below 2000 Turkish Liras per month) tended to adjust more.

\subsubsection{Influence of Gender}

An independent samples t-test was applied to compare the evaluations of the male and female respondents. A statistically significant difference was found for the cautious spending between male $\left(\mu_{\text {male }}\right.$ $=3.57 \pm 0.89)$ and female $\left(\mu_{\text {female }}=3.77 \pm 0.77 ; t=2.25\right.$, $\mathrm{p}=0.03$ ) respondents. In addition, gender constituted a significant difference in the quest for low price dimension $\left(\mu_{\text {male }}=3.34 \pm 0.90, \mu_{\text {female }}=3.58 \pm 0.84\right.$; $t=2.67, p=0.01)$. According to the mean values, both in the cautious spending and quest for low price categories, the female respondents adjusted more than the males (Table 7).

At the $p<0.05$ level, there were statistically significant differences between the male and female respondents for the statements "I judge products and services in a new way", "I became more of a comparative shopper", "I buy less of everything" and "Instead of shopping, I am contented with window shopping" (Table 8 ) in the cautious spending category. The female respondents had higher scores for the statements under the cautious spending demonstrating that they adjusted more.

Table 7: The Influence of Gender on Adjustment Categories

\begin{tabular}{|l|c|c|c|}
\hline \multicolumn{1}{|c|}{ Adjustment Categories } & $\boldsymbol{\mu} \pm \mathbf{s d}$ & t & $\mathbf{p}^{*}$ \\
\hline Cautious Spending & & & \\
\hline Male & $3.53 \pm 0.87$ & 2.25 & 0.03 \\
\hline Female & $3.73 \pm 0.76$ & & \\
\hline Quest for Low Price & & 2.67 & \multirow{2}{*}{0.01} \\
\hline Male & $3.33 \pm 0.93$ & $3.60 \pm 0.85$ & \\
\hline Female & & & \\
\hline
\end{tabular}

* $p<0.05$

In the quest for low price category, there were significant differences at the $p<0.05$ level for the statements, "I shop for specials and bargains more than I used to", "I shop at cut-rate stores more than before", and "I pay more attention to sales promotions". Also for these statements, the mean scores of the female respondents were higher than those of the males.

According to the results, $\mathrm{H}_{5}$ was partially supported. Gender constituted a significant difference in the categories of cautious spending and quest for low price adjustments, as the female respondents adjusted their consumption behavior more than did the males.

\section{Table 8: Significant T-Test Results Regarding Gender and Adjustment Categories}

\begin{tabular}{|c|c|c|c|c|}
\hline Adjustment Categories & Gender & $\boldsymbol{\mu} \pm \mathbf{s d}$ & $\mathbf{t}$ & $\mathbf{p}^{*}$ \\
\hline \multicolumn{5}{|l|}{ Cautious Spending } \\
\hline \multirow{2}{*}{ I judge products and services in a new way. } & Male & $3.50 \pm 1.17$ & \multirow{2}{*}{3.27} & \multirow{2}{*}{0.01} \\
\hline & Female & $3.85 \pm 0.98$ & & \\
\hline \multirow{2}{*}{ I became more of a comparative shopper. } & Male & $3.73 \pm 1.25$ & \multirow{2}{*}{2.24} & \multirow{2}{*}{0.03} \\
\hline & Female & $3.99 \pm 1.08$ & & \\
\hline \multirow{2}{*}{ I buy less of everything. } & Male & $3.29 \pm 1.26$ & \multirow{2}{*}{2.29} & \multirow{2}{*}{0.02} \\
\hline & Female & $3.57 \pm 1.15$ & & \\
\hline \multirow{2}{*}{ Instead of shopping, I am contented with window shopping. } & Male & $2.87 \pm 1.24$ & \multirow{2}{*}{2.88} & \multirow{2}{*}{0.00} \\
\hline & Female & $3.21 \pm 1.11$ & & \\
\hline \multicolumn{5}{|l|}{ Quest for Low Price } \\
\hline \multirow{2}{*}{ I shop for specials and bargains more than I used to. } & Male & $3.39 \pm 1.25$ & \multirow{2}{*}{2.69} & \multirow{2}{*}{0.01} \\
\hline & Female & $3.72 \pm 1.10$ & & \\
\hline \multirow{2}{*}{ I shop at cut-rate stores more than before. } & Male & $3.27 \pm 1.20$ & \multirow{2}{*}{2.64} & \multirow{2}{*}{0.01} \\
\hline & Female & $3.59 \pm 1.12$ & & \\
\hline \multirow{2}{*}{ I pay more attention to sales promotions. } & Male & $3.31 \pm 1.19$ & \multirow{2}{*}{2.41} & \multirow{2}{*}{0.02} \\
\hline & Female & $3.60 \pm 1.15$ & & \\
\hline
\end{tabular}

$* p<0.05$ 


\subsubsection{Influence of Marital Status}

In order to test whether marital status constituted a significant difference in the adjustment levels of consumers, an independent t-test analysis was conducted. A statistically significant difference was found for the simplicity in purchase and distribu- tion between single $\left(\mu_{\text {single }}=2.90 \pm 0.79\right)$ and married respondents $\left(\mu_{\text {married }}=3.17 \pm 0.90 ; t=-3.330, p=0.001\right)$. Also in the promotion adjustments category, the adjustment levels of the single $\left(\mu_{\text {single }}=3.32 \pm 0.90\right)$ and married respondents $\left(\mu_{\text {married }}=3.57 \pm 0.91 ; t=-2.781\right.$, $p=.006$ ) differed significantly.

Table 9: The Influence of Marital Status on Adjustment Categories

\begin{tabular}{|c|c|c|c|}
\hline Adjustment Categories & $\mu \pm s d$ & $\mathbf{t}$ & $\mathbf{p}^{*}$ \\
\hline \multicolumn{4}{|l|}{ Simplicity in Purchase and Distribution } \\
\hline Married & $3.17 \pm 0.90$ & \multirow{2}{*}{-3.33} & \multirow{2}{*}{0.00} \\
\hline Single & $2.90 \pm 0.79$ & & \\
\hline \multicolumn{4}{|l|}{ Promotion Adjustments } \\
\hline Married & $3.57 \pm 0.91$ & \multirow{2}{*}{-2.79} & \multirow{2}{*}{0.01} \\
\hline Single & $3.32 \pm 0.90$ & & \\
\hline
\end{tabular}

$* p<0.05$

In the simplicity in purchase and distribution category, statistically significant differences were found at the $p<.05$ level for the statements, "I became a do-it-yourself person" and "I prefer local rather than foreign brands". There were significant differences at the $p<.05$ level for the statements, "I believe in advertising claims less than I used to" and "I ask the salesperson more questions now before I make a purchase", in the promotion adjustments category.

Therefore, $\mathrm{H}_{6}$ was partially supported for the simplicity in purchase and distribution, and promotion adjustments dimensions, since the married respondents adjusted more (see Table 10).

Table 10: Significant T-Test Results Regarding Marital Status and Adjustment Categories

\begin{tabular}{|c|c|c|c|c|}
\hline Adjustment Categories & $\begin{array}{c}\text { Marital } \\
\text { Status }\end{array}$ & $\boldsymbol{\mu} \pm \mathbf{s d}$ & $\mathbf{t}$ & $\mathbf{p}^{*}$ \\
\hline \multicolumn{5}{|l|}{ Simplicity in Purchase and Distribution } \\
\hline \multirow{2}{*}{ I became a do-it-yourself person. } & Married & $3.03 \pm 1.29$ & \multirow{2}{*}{-3.25} & \multirow{2}{*}{0.00} \\
\hline & Single & $2.62 \pm 1.21$ & & \\
\hline \multirow{2}{*}{ I prefer local rather than foreign brands. } & Married & $3.63 \pm 1.26$ & \multirow{2}{*}{-3.04} & \multirow{2}{*}{0.00} \\
\hline & Single & $3.27 \pm 1.14$ & & \\
\hline \multicolumn{5}{|l|}{ Promotion Adjustments } \\
\hline \multirow{2}{*}{ I believe in advertising claims less than I used to. } & Married & $3.76 \pm 1.16$ & \multirow{2}{*}{-2.14} & \multirow{2}{*}{0.03} \\
\hline & Single & $3.51 \pm 1.19$ & & \\
\hline \multirow{2}{*}{ I ask the salesperson more questions now before I make a purchase. } & Married & $3.68 \pm 1.14$ & \multirow{2}{*}{-3.05} & \multirow{2}{*}{0.00} \\
\hline & Single & $3.33 \pm 1.22$ & & \\
\hline
\end{tabular}

$* p<0.05$

\section{CONCLUSION}

In this study, seven adjustment dimensions, including 35 statements were revealed. Four of these dimensions related to the marketing mix elements were similar to the findings of the previous studies (Ang, 2001a, 2001b; Ang et al., 2000; Shama, 1978, 1981). In addition to these 4P dimensions, Shama (1978) found a dimension named "general". On the other hand, Ang et al., 2000 suggested "shopping" adjustments instead of "distribution" and added the fifth dimension as "general reactions". While these studies had five dimensions, in our study, the items were categorized under seven dimensions. Other than the dimensions related to product, price, distribution, and promotion, this study revealed the dimensions of "cautious spending", "financial anxiety", and "awareness".

This study also demonstrated the influence of demographic factors on consumption adjustments, which differ with respect to consumers' gender, age, marital status, occupation, and income.

According to the results, in the cautious spending and quest for low price dimensions, the factors creating significant differences were occupation, income level, and gender. While age, occupation, and marital 
status influenced the promotion adjustments, occupation and income affected level of adjustments in the financial anxiety. In the "simplicity in purchase and distribution" category, differences occurred with respect to occupation and marital status. In general, consumption behavior was adjusted more by females, lower income groups, laborers, teachers, and other occupation groups including doctors, nurses, academics, press members, librarians, government officers, electronic technicians, software specialists, and security personnel. While findings related to females contradict with the general belief that they consume more, $80 \%$ of the female respondents had low income, below 2000 Turkish Liras per month. Therefore, greater level of adjustments of the females to the crisis might be related to income as well as gender.

A limitation of this study could be the sample distribution that students consisted of $27.2 \%$ of the sample. Students might not feel the impact of crisis since they don't earn their own money, rather they are financially supported by their parents, who could influence or restrict their spendings. In this respect, students might have adjusted their consumption behavior less which might in return have influenced the results by decreasing the mean values. On the other hand, the laborers, who made up $37.4 \%$ of the sample, would not have had such an impact on the results compared to the students since laborers are supposed to spend the money they earn more rationally.

This study, in fact, is a pilot study that attempts to develop a scale to measure consumption adjustments during crisis. The Cronbach Alpha values and the total variance explained show that the scale is reliable and sufficient. On the other hand, the "awareness" dimension requires further improvement. In future studies, a focus group study can be conducted to explore additional items related to this dimension. In addition, the impact of crises on various issues such as brand loyalty abd store loyalty should be investigated in future studies.

Furthermore, the sample was confined to Izmir, and a broader sample from different areas of Turkey would more accurately reflect consumption adjustments over the whole country. In addition, the scale can be tested in different cultures and countries at various levels of economic development. A future study focusing on a cross-cultural analysis could also be helpful in increasing our knowledge on this subject. Longitudinal studies, measuring the impacts of a specific crisis in different time periods, or comparative studies on the effects of various crises will be helpful in thoroughly understanding consumers' adjustment behavior during crises.

This study also has practical implications. The results show that during crisis, skepticism about promotion activities increases, so that instead of spending on promotion, firms could reduce prices. It could be a useful strategy considering consumers' "quest for low prices" and "cautious spending". Besides, in designing promotional activities, marketers should emphasize informative claims or messages more since collecting information from salespeople, advertisements, etc. becomes more important for consumers during crisis. Another crucial factor is product durability. Marketers of luxury goods should have contingency plans for crisis terms because consumers adjust their consumption behavior by giving priority to their nececities while decreasing their luxury consumption. Consumers' tendency to purchase local brands increases during crisis. Marketers of local brands should benefit from crisis by working harder to improve their brand equity. Since consumers tend to shop at smaller stores and in neighborhood; firms could expand in these areas accordingly.

\section{END NOTES}

i http://www.imf.org/external/pubs/ft/weo/2009/01/pdf/text. pdf $(20,09.2010)$.

ii See "Marketing in a Recession: Comments from Our Read- ers", Journal of Marketing, 39 (3), 78.

ii http://www.haber7.com/haber/20090430/Kriz-tuketim-aliskanliklarimizi-ne-kadar-etkiledi.php, (20.09.2010).

\section{REFERENCES}

Allen, R. E., \& Snyder, D. (2009) "New Thinking on the Financial Crisis". Critical Perspectives on International Business, 5(1-2): 36-55.

Altunışık, R., Torlak, Ö., \& Özdemir, Ş. (2003) Ekonomik
Kriz ve Değişen Alışveriş̧ Alı̧̧kanlıkları Üzerine Bir Araştırma [A Research on Economic Crisis and Changing Consumption Habits], Paper presented at the 8th National Congress of Marketing, Kayseri, Turkey. 
Ang, S. H., Siew, M. L., \& Philip, K. (2000) "The Asian Apocalypse: Crisis Marketing for Consumers and Businesses", Long Range Planning, 33: 97-119.

Ang, S. H. (2001a) "Crisis Marketing: A Comparison across Economic Scenarios", International Business Review, 10: 263-284

Ang, S. H. (2001b) "Personality Influences on Consumption: Insights from the Asian Economic Crisis", Journal of International Consumer Marketing, 13 (1): 5-20.

Aydin, K. (2009) "Küresel Kriz ve Türkiye [The Global Crisis and Turkey]", http://perakende.org/haber. php?hid=1231342495, (31.05.2009)

Cohen, J. (1969) Statistical Power Analysis for the Behavioral Sciences, New York, Academic Press.

Duygan, B. (2005) Aggregate Shocks, Idiosyncratic Risk, and Durable Goods Purchases: Evidence from Turkey's 1994 Financial Crisis, European University Institute Finance and Consumption Program Working Paper.

Fernandez, J. (2009) "Crunchonomics: Understanding Consumers in the Recession", Marketing Week, April 23: 32.

Frankenberg, E., Thomas, D., \& Beegle, K. (1999) The Real Costs of Indonesia's Economic Crisis: Preliminary Findings from the Indonesia Family Life Surveys, Labor and Population Program Working Paper, RAND DRU 2064. Santa Monica, RAND.

French, S., Leyshon, A., \& Thrift, N. (2009) "A Very Geographical Crisis: The Making and Breaking of the 2007-2008 Financial Crisis" Cambridge Journal of Regions, Economy and Society, 2: 287-302.

Friedman, J. \& Levinsohn, J. (2002) “The Distributional Impacts of Indonesia's Financial Crisis on Household Welfare: A 'Rapid Respond' Methodology', The World Bank Economic Review, 16 (3): 397-423.

Krejcie, R. V. \& Morgan, D. W. (1970) “Determining Sample Size for Research Activities", Educational and Psychological Measurement, 30: 607-610.

Malhotra, N. K. (2007) Marketing Research: An Applied Orientation, 5th ed., Upper Saddle River, NJ, Pearson/ Prentice Hall.

McKenzie, D. J. (2006) "The Consumer Response to the Mexican Peso Crisis", Economic Development and Cultural Change, 55 (1): 139-172.

Özkan, G. (2008) "Küresel Ekonomik Kriz: Makroekonomik Bir Yaklaşım [The Global Financial Crisis: A Macroeconomical Approach]" Banking Regulation and Supervision Agency Special Publication, http://www.york.ac.uk/depts/econ/documents/misc/ financial_crisis_macroeconomic_explanation.pdf, (19.04.2009).

Reinhart, C. M. \& Rogoff, K. S. (2008) "Is the 2007 US Sub-Prime Financial Crisis So Different? An International Historical Comparison", (NBER Working Paper, No. 13761), http://www.nber.org/papers/w13761, (20.10.2009).

Roscoe, J. T. (1975) Fundamental Research Statistics for the Behavioral Sciences (2nd ed.), New York: Holt, Rinehart and Winston.

Selçuk, B. \& Yılmaz, N. (2010) "Küresel Finansal Sistemde Değişim ve Türkiye'ye Etkileri [The Alteration in the Global Financial System and Its Effects on Turkey]". http://bsy.marmara.edu.tr/Konferanslar/2008/33.pdf, (19.04.2009).

Shama, A. (1978) "Management and Consumers in an Era of Stagflation”, Journal of Marketing, 42: 43-52.

Shama, A. (1981) "Coping with Stagflation: Voluntary Simplicity", Journal of Marketing, 45: 120-134.

Sheth, J. N. (1970) "Multivariate Analysis in Marketing", Journal of Advertising Research, 10 (1): 29-39.

Susam, N. \& Bakkal, U. (2008) "Kriz Süreci Makro Değişkenleri ve 2009 Bütçe Büyüklüklerini Nasıl Etkileyecek? [How will the Crisis Period Affect Macro Variables and 2009 Budget Sizes?]", Maliye Dergisi, 155: 72-88.

Uzunoğlu, S. (2009) "Global Kriz: Ne Zaman ve Nasil Sona Erecek? [The Global Crisis: When and How Will it End?]", TGSK Akademi, 4 (2): 80-88.

Whitney, M. (2009) "Credit Cards are the Next Credit Crunch", The Wall Street Journal, March 11. http://online.wsj.com/article/SB123664459331878113.html, (20.10.2009).

Yang, B., Prescott, N. \& Bae, E. (2001) "The Impact of Economic Crisis on Health-Care Consumption in Korea”, Health Policy and Planning, 16 (4): 372-385.

Yıldız, Z. \& Durgun, A. (2010) "2008 Küresel Ekonomik Krizi ve Turizm Sektörü Üzerine Etkileri [The 2008 Global Economic Crisis and Its Effects on the Tourism Sector]", Vizyoner Dergisi, 2 (1): 1-15. 
